infections, nephrosis and hypocomplementacmic glomerulonephritis. Clin Exp Immunol 28:6

12. Gallin J1, Clark RA, Kimball HR 1973 Granulocyte chemotaxis: an improved in vitro assay employing ${ }^{51} \mathrm{Cr}$-labeled granulocytes. J Immunol 110:233

13. Garvin JE 1961 Factors affecting the adhesiveness of human leukocytes and platelets in vitro. J Exp Med 114:51

14. Henson PM 1971 Interaction of cells with immune complexes: adherence, release of constituents and tissue injury. J Exp Med 134:114s

15. Jacob HS 1978 Granulocyte-complement interaction, a beneficial antimicrobial mechanism that can cause disease. Arch Intern Med 138:461

16. Jacob HS, Craddock PR, Hammerschmidt DE, Moldow CF 1980 Complement-induced granulocyte aggregation: an unsuspected mechanism of disease. N Engl J Med 302:789

17. Kvarstein B 1969 A methodological study of human leukocyte adhesiveness to glass beads. Scand J Clin Lab Invest 23:259

18. MacGregor RR 1976 The effect of anti-inflammatory agents and inflammation on granulocyte adherence: evidence for regulation by plasma factors. Am J Med 61:597

19. MacGregor RR 1977 Granulocyte adherence changes induced by hemodialysis, endotoxin, epinephrine and glucocorticoids. Ann Intern Med 86:35

20. McGillen JJ, Phair JP 1979 Adherence, augmented adherence, and aggregation of polymorphonuclear leukocytes. J Infect Dis 139:69

21. Norman ME, Miller ME 1973 Spontaneous chemotaxis in patients with glomerulonephritis and the nephrotic syndrome. J Pediatr 83:390

22. Norman ME, Miller ME 1974 Spontaneous chemotaxis in acute glomerulonephritis: demonstration of a positive correlation with disease activity. J Pediatr 85:20

23. Notani GW, Kenyon AJ, Zurier RB 1976 Altered neutrophile function induced by serum from patients with systemic lupus erythematosus. In; Friedman $\mathrm{H}$ Escobar MR, Reichard SM (eds): Advances in Experimental Biology, Reticuloendothelial System in Health and Disease, Vol 73, Part B. New York Plenum Press, pp 147-154

24. O'Flaharty JT, Craddock PR, Jacob HS 1978 Effect of intravascular complement activation on granulocyte adhesiveness and distribution. Blood 51:731

25. Penny R, Galton DAG, Scott JT, Eisen V 1966 Studies on neutrophile function. I. Physiological and pharmacological aspects. Br J Haematol 12:623

26. Ruley EJ, Huang S, Plaut J, Morris N 1976 Defective phagocyte adherence in acute post streptococcal glomerulonephritis: clinical and laboratory observations. J Pediatr $89 \cdot 748$

27. Spitzer RE, Stitzel AE, Pauling VL, Davis NC, West CD 1971 The antigenic and molecular alterations of $\mathrm{C} 3$ in the fluid phase during an immune reaction in normal human serum. J Exp Med 134:656

28. Strife CF, McAdams AJ, McEnery PT, West CD 1974 Hypocomplementemic and normocomplementemic acute nephritis in children: a comparison with respect to etiology, clinical manifestation, and glomerular morphology. J Pediatr 84:29

29. Strife CF, McDonald BM, Ruley EJ, McAdams AJ, West CD 1976 Shun nephritis: the nature of the serum cryoglobulins and their relation to the complement profile. J Pediatr 88:403

30. Strife CF, McEnery PT, McAdams AJ, West CD 1977 Membranoproliferative glomerulonephritis with disruption of the glomerular basement membrane. Clin Nephrol 7:65

31. Svensson BO 1975 Serum factors causing impaired macrophage function in systemic lupus erythematosus. Scand J Immunol 4:145

32. Svensson BO, Hedberg H 1973 Impaired phagocytosis by macrophages in SLE. Scand J Rheumatol 2:78

33. Tan EM, Cohen AS, Fries JF, Masi AT, McShane DM, Rothfield NF, Schaller JG, Talal N, Winchester RJ 1982 The 1982 revised criteria for the classification of systemic lupus erythematosus. Arthritis Rheum 25:1271

34. Tibbling G 1970 Glycerol uptake in leukocytes and thrombocytes. Scand J Clin Lab Invest 26:185

35. Unanue ER, Dixon FJ 1967 Experimental glomerulonephritis: immunological events and pathogenetic mechanisms. Adv Immunol 6:1

36. Vallota EH, Forristal J, Spitzer RE, Davis NC, West CD 1970 Characteristics of a non-complement-dependent $\mathrm{C} 3$-reactive complex formed from factors in nephritic and normal serum. J Exp Med 131:1306

37. Weissmann G, Zurier RB, Spieler PJ, Goldstein IM 1971 Mechanisms of lysozomal enzyme release from leukocytes exposed to immune complexes and other particles. J Exp Med 134:149s

38. West CD 1976 Pathogenesis and approaches to therapy of membranoproliferative glomerulonephritis. Kidney Int 9:1

39. Wood WB 1951 Studies on the cellular immunology of acute bacterial infections. Harvey Lect 47:72

40. Wyatt RJ, McAdams AJ, Forristal J, Snyder J, West CD 1979 Glomerular deposition of complement-control proteins in acute and chronic glomerulonephritis. Kidney Int 16:505

41. Zurier RB 1976 Reduction of phagocytosis and lysozomal enzyme release from human leukocytes by serum from patients with systemic lupus erythematosus. Arthritis Rheum 19:73

42. The authors express their appreciation to Mr. Jeffrey Breslin, Mr. William Punch, and Mrs. Maura Tobler for their technical assistance and to Mrs. Karen Kilgo for her secretarial help.

43. Requests for reprints should be addressed to: C. Frederic Strife, M.D., Division of Pediatric Nephrology, Children's Hospital Research Foundation, Elland and Bethesda Avenues, Cincinnati, OH 45229

44. Received for publication April 18, 1983

45. Accepted for publication October 18, 1983

\title{
Postheparin Plasma Lipase Activities and Plasma Lipoproteins in Newborn Infants
}

\author{
LIISA ROVAMO, ${ }^{(42)}$ MARJA-RIITTA TASKINEN, TIMO KUUSI, ESKO A. NIKKILÄ \\ CHRISTIAN EHNHOLM, AND KARI O. RAIVIO \\ Children's Hospital and Third Department of Medicine, University of Helsinki, and \\ National Public Health Institute, Helsinki, Finland
}

Summary

We measured blood glucose, serum insulin and apoprotein AI and A-II, and triglycerides and cholesterol contained in serum lipoprotein fractions of 24 full-term newborn infants who underwent exchange transfusion with heparinized blood for hematological reasons. The values were similar to those previously reported for healthy newborn infants. We also measure lipoprotein and hepatic lipase activities with specific methods. Fifteen minutes after an intravenous heparin bolus of $100 \mathrm{IU} / \mathrm{kg}$, mean lipoprotein lipase activity in infants $(16.0 \mu \mathrm{mol}$ free fatty $\mathrm{acids} / \mathrm{ml} / \mathrm{h})$ was as in adults. In contrast, hepatic lipase activity was significantly higher in infants $(54.3 \mu \mathrm{mol}$ free fatty acids $/ \mathrm{ml} / \mathrm{h})$ than in adults. There was no sex difference in the infant lipase activities. Lipoprotein and hepatic lipase activities were also measured 5 and 15 min after a heparin bolus of 10 and $50 \mathrm{IU} / \mathrm{kg}: 10 \mathrm{IU} / \mathrm{kg}$ released only part of the lipase activities. In addition, the two lipases were measured during the exchange transfusion. Although $92 \%$ of the original infant blood was removed, lipoprotein lipase activity remained constant. In contrast, hepatic lipase activity decreased considerably. In infants, postheparin lipolytic activity is a conventional measure of lipoprotein lipase. Lipoprotein and hepatic 
lipases comprise $95 \%$ of postheparin lipolytic activity. In our infants, hepatic lipase activity was 3.4 times higher than lipoprotein lipase activity. Hence, it seems unjustified to use postheparin lipolytic activity as a measure of lipoprotein lipase.

\section{Abbreviations}

LPL, lipoprotein lipase

PHLA, postheparin lipolytic activity

VLDL, very low density lipoprotein

LDL, low density lipoprotein

HDL, high density lipoprotein

FFA, free fatty acids

Within a few hours after birth, fat becomes the main metabolic fuel: plasma free fatty acid and glycerol concentrations increase, the level of blood ketone bodies becomes elevated, and the respiratory quotient decreases (15). Fat metabolism in newborn infants has, however, not been characterized in detail.

LPL hydrolyzes triglycerides in chylomicrons and VLDL of plasma. Lipoprotein lipase is the rate-limiting factor for clearance of fat from the circulation in adults $(6,33,37)$. Lipoprotein lipase is released by heparin from the vascular endothelial surface of muscle and fat tissue.

Hepatic lipase is released by heparin from the vascular endothelial surface of the liver $(24,30)$. Its role in lipoprotein metabolism has not been established yet $(14,22,23,29)$.

In newborn infants, PHLA is a conventional measure of lipoprotein lipase activity $(8,20,41)$. Hepatic lipase, however, forms a substantial part of postheparin lipolytic activity $(18,37)$. Therefore, the activities of the two lipases should be measured separately in infants, too.

In the present study, we measured, with specific methods, lipoprotein and hepatic lipase activities in the postheparin plasma of newborn infants who, because of hematological reasons, underwent an exchange transfusion with fresh heparinized blood $(25,35)$. We also measured other parameters of fat and carbohydrate metabolism.

\section{MATERIALS AND METHODS}

Patients. We studied 24 newborn infants, 10 girls and 14 boys, born to healthy mothers without major pregnancy complications. Four babies were delivered by cesarean section, the others through vaginal route.
All infants were born at term: the mean gestational age was 38 weeks (range, 37-41 weeks). The mean birth weight was $3470 \mathrm{~g}$ (range, 2800-4220 g). One infant had an Apgar score (1) of 4 at $1 \mathrm{~min}$ of age but 9 at $5 \mathrm{~min}$. All others had normal Apgar scores ranging from 7 to 10 at $1 \mathrm{~min}$ of age.

Twenty-two infants underwent an exchange transfusion for hematological reasons. In the Children's Hospital of Helsinki University, exchange transfusions are routinely performed with fresh heparinized blood from voluntary donors (17). Nineteen of the infants had blood group incompatibility ( $\mathrm{Rh}$ in 10 cases, $\mathrm{ABO}$ in 9 cases): the mean umbilical venous hemoglobin level was $14.9 \mathrm{~g} / \mathrm{dl}$ (range, 9.2-18.8), mean reticulocyte count was $9.0 \%$ (range, $3.2-19.4$ ), and mean bilirubin level was $12.9 \mathrm{mg} /$ $\mathrm{dl}$ (range, 6.1-22.1). Three infants, aged 4 to 6 days, had "simple" hyperbilirubinemia with pre-exchange bilirubin levels of 19.5 to $23.6 \mathrm{mg} / \mathrm{dl}$.

Two other infants underwent, because of polycythemia, a partial plasma exchange with fresh frozen heparinized plasma. Their pre-exchange umbilical venous hemoglobin values were 25.3 and $25.6 \mathrm{~g} / \mathrm{dl}$.

All infants were in good condition and on breast feeding. Their postnatal ages ranged from 6 to $131 \mathrm{~h}$ at the time of the exchange. On the average, infants fasted $4 \mathrm{~h}$ that elapsed between the decision and performance of the exchange transfusion.

Study protocol. An umbilical vein catheter, kept open with saline, was inserted for the exchange transfusion. A blood sample was taken through the catheter to measure serum triglyceride and cholesterol (total, VLDL, LDL, HDL), serum insulin, serum apolipoprotein A-I and A-II, blood glucose, plasma lipoprotein, and hepatic lipase activities. Thereafter, a heparin (Medica, Helsinki, Finland) bolus of 10,50 , or $100 \mathrm{IU} / \mathrm{kg}$ was injected through the catheter. Blood samples were taken at 5 and 15 min after the heparin dose to measure lipase activities; part of the 15 -min sample was used for routine laboratory studies. In four infants, studied with a heparin dose of $100 \mathrm{IU} / \mathrm{kg}$, a simultaneous $15-$ min sample was taken from a scalp vein to measure peripheral lipase activities. The conventional exchange transfusion was then performed: removal of $15 \mathrm{ml}$ of infant blood alternated with replacement of $15 \mathrm{ml}$ of fresh heparinized donor blood. One unit of donor blood (mean volume, $500 \mathrm{ml}$ ) contains $2250 \mathrm{IU}$ heparin. When 100 and $200 \mathrm{ml} / \mathrm{kg}$ of blood had been exchanged, blood samples were taken to measure the activities of lipoprotein and hepatic lipases. The blood exchange lasted, on the average, $65 \mathrm{~min}$ and the total volume of blood exchanged was $200 \mathrm{ml}$ / $\mathrm{kg}$. At the end of the exchange transfusion, the effect of heparin

Table 1. Parameters of fat and carbohydrate metabolism

\begin{tabular}{|c|c|c|c|c|c|c|c|c|c|}
\hline \multirow{2}{*}{ Compound } & \multirow{2}{*}{ (unit) } & \multicolumn{7}{|c|}{ Age group } & \multirow{2}{*}{$\begin{array}{l}\text { Significance } \\
\text { of } \\
\text { difference } 1\end{array}$} \\
\hline & & No. & & $6-48 h$ & & No. & & $49-131 h$ & \\
\hline Glucose & $(\mathrm{mg} / \mathrm{dl})$ & 14 & 48.6 & (34.2- & $66.6)^{2}$ & 10 & 57.6 & $(39.6-88.2)$ & NS \\
\hline Insulin & $(\mu \mathrm{U} / \mathrm{mI})$ & 14 & 16.7 & ( $7.3-$ & $31.0)$ & 10 & 9.2 & $(4.2-20.8)$ & 0.0023 \\
\hline Triglycerides & $(\mathrm{mg} / \mathrm{d} l)$ & 14 & 87.1 & $(46.6-$ & $151)$ & 10 & 116 & $(66.0-157)$ & 0.0095 \\
\hline VLDL-triglycerides & $(\mathrm{mg} / \mathrm{dl})$ & 12 & 27.3 & $(12.3-$ & 59.81 & 8 & 44.9 & $(22.0-90.6)$ & 0.020 \\
\hline LDL -triglycerides & $(\mathrm{mg} / \mathrm{dl})$ & 12 & 28.2 & ( $8.8-$ & $52.8)$ & 8 & 36.1 & $(26.4-51.0)$ & NS \\
\hline HDL-triglycerides & $(\mathrm{mg} / \mathrm{dl})$ & 12 & 30.8 & $(20.2-$ & $51.0)$ & 8 & 26.4 & $(17.6-35.2)$ & NS \\
\hline Cholesterol & $(\mathrm{mg} / \mathrm{d} l)$ & 13 & 64.2 & $(46.4-$ & $75.9)$ & 10 & 88.6 & $(66.2-115)$ & 0.00015 \\
\hline VLDL-cholesterol & $(\mathrm{mg} / \mathrm{d} l)$ & 11 & 4.4 & $10.8-$ & $11.2)$ & 8 & 6.8 & $(1.9-10.8)$ & NS \\
\hline LDL -cholesterol & $(m g / d l)$ & 12 & 32.0 & (21.3- & 40.21 & 8 & 47.6 & $(26.7-72.4)$ & 0.0054 \\
\hline HDL-cholesterol & $(\mathrm{mg} / \mathrm{dl})$ & 12 & 26.5 & $(19.4-$ & $31.3)$ & 8 & 36.6 & $(20.9-51.1)$ & 0.0016 \\
\hline HDL2-cholesterol & $(\mathrm{mg} / \mathrm{d} \mathrm{l})$ & 8 & 16.2 & $(10.8-$ & 20.51 & 5 & 26.5 & $(19.0-37.2)$ & 0.0034 \\
\hline HDL3-cholesterol & $(\mathrm{mg} / \mathrm{dl})$ & 8 & 10.2 & $18.1-$ & $11.6)$ & 5 & 13.5 & $(9.7-15.5)$ & 0.023 \\
\hline Apolipoprotein A 1 & $(\mathrm{mg} / \mathrm{dl})$ & 14 & 82.2 & $(62.4-$ & $92.7)$ & 10 & 91.3 & $(72.8-112)$ & 0.026 \\
\hline Apolipoprotein A II & $(\mathrm{mg} / \mathrm{dl})$ & 14 & 27.3 & $(21.8-$ & $31.6)$ & 10 & 29.3 & $(21.8-36.1)$ & NS \\
\hline
\end{tabular}

\footnotetext{
${ }^{1}$ Mann-Whitney one-tail test

2 Mean (range)
} 
was routinely neutralized by protamine sulfate. Heart rate, respiration, and central venous presure were continuously monitored. All infants tolerated the exchange well.

The Ethical Committee of The Children's Hospital had accepted the study protocol.

Measurement of plasma lipoproteins. Using a Ti-50 rotor in a Beckman L7-70 ultracentrifuge (Beckman Instruments, Inc., Palo Alto, Ca) VLDL, LDL, HDL2, and HDL3 were separated by sequential spinning at densities of $1.006,1.063$, and $1.125 \mathrm{~g} /$ $\mathrm{ml}$ for 18,24 , and $56 \mathrm{~h}$, respectively.

Cholesterol and triglyceride concentrations in serum and lipoprotein fractions were measured with an enzymatic method (kit No. 187313 and 297771, Boehringer Diagnostica GmbH, Mannheim, West Germany). Apoprotein A-I and A-II concentrations were measured with a radial immunodiffusion method (5).

Measurement of lipase activities. Blood samples were collected into chilled heparinized tubes kept in ice. They were immediately centrifuged and the plasma was stored at $-20^{\circ} \mathrm{C}$ until assayed. The lipoprotein and hepatic lipase activities of the postheparin plasma were measured with the immunochemical method of Huttunen et al. (18): lipoprotein lipase was measured after inactivating hepatic lipase with a specific antiserum; hepatic lipase was measured at $1 \mathrm{M} \mathrm{NaCl}$ concentration inactivating lipoprotein lipase, no serum was added. The activities are expressed in micromoles of free fatty acid released from radioactive triolein substrate per $1 \mathrm{ml}$ of plasma in $1 \mathrm{~h}(\mu \mathrm{mol} \mathrm{FFA} / \mathrm{ml} / \mathrm{h})$.

Statistical methods. Statistical analyses were performed using the Mann-Whitney and Wilcoxon one-tail test (36) of program $3 \mathrm{~S}$ of the BMDP statistical software (9) adapted to Cii Honeywell Bull computer DPS 8 in Helsinki University Hospital.

\section{RESULTS}

Parameters of fat and carbohydrate metabolism. All infants were normoglycemic (Table 1). Comparing infants younger and older than $48 \mathrm{~h}$, we found the serum insulin concentration decreased with age $(P<0.01)$. In five infants, the insulin concentration exceeded $20 \mu \mathrm{U} / \mathrm{ml}$; three of them were younger than $24 \mathrm{~h}$. The serum triglyceride concentrations (total, VLDL, LDL, HDL) varied considerably. This may partially result from the different fasting periods of the infants. However, comparing infants younger and older than $48 \mathrm{~h}$, we found that the total triglyceride $(P<0.01)$ and VLDL-triglyceride $(P<0.05)$ concentrations increased with age. Similarly, the total cholesterol $(P$ $<0.001)$, LDL-cholesterol $(P<0.01)$, HDL-cholesterol $(P<$ $0.01)$, HDL2-cholesterol $(P<0.01)$, and HDL3-cholesterol $(P<$ $0.05)$ concentrations increased with age. Also, the total apolipoprotein A-I concentration increased with age $(P<0.05)$.

Lipoprotein and hepatic lipases. There were no measurable lipase activities in the blood samples taken before heparin administration.

Fifteen minutes after a heparin bolus of $100 \mathrm{IU} / \mathrm{kg}$, the mean activities in 16 newborn infants were $16.0 \mu \mathrm{mol} \mathrm{FFA} / \mathrm{ml} / \mathrm{h}$ (SEM \pm 1.69 ) for lipoprotein lipase (Fig. $1 A$ ) and $54.2 \mu \mathrm{mol} \mathrm{FFA} / \mathrm{ml}$ / h. $(\mathrm{SEM} \pm 4.38)$ for hepatic lipase (Fig. $1 B)$; the values for the girls $(n=5)$ and boys $(n=11)$ were similar $(P>0.1)$. For comparison, lipoprotein and hepatic lipase activities were measured in 34 healthy medical students. As Figure $1 \mathrm{~A}$ shows, lipoprotein lipase activities were similar in newborn infants and adults. However, the mean activity of hepatic lipase (Fig. $1 B$ ) was in newborn infants 1.8 times the activity of adult males and 2.7 times the activity of adult females.

Lipoprotein lipase activity was found to be independent of postnatal age. Hepatic lipase activity in infants younger than 24 h $(n=6$; mean, $42.3 \mu \mathrm{mol} \mathrm{FFA} / \mathrm{ml} / \mathrm{h}$; range, 20.9-62.7) was lower $(P<0.05)$ than hepatic lipase activity in older infants $(n$ $=10$; mean, $61.4 \mu \mathrm{mol} \mathrm{FFA} / \mathrm{ml} / \mathrm{h}$; range, 37.5-88.4).

In seven infants, we also measured lipoprotein and hepatic lipase activities $5 \mathrm{~min}$ after heparin administration. Lipoprotein $(P<0.05)$ and hepatic $(P<0.01)$ lipase activities increased

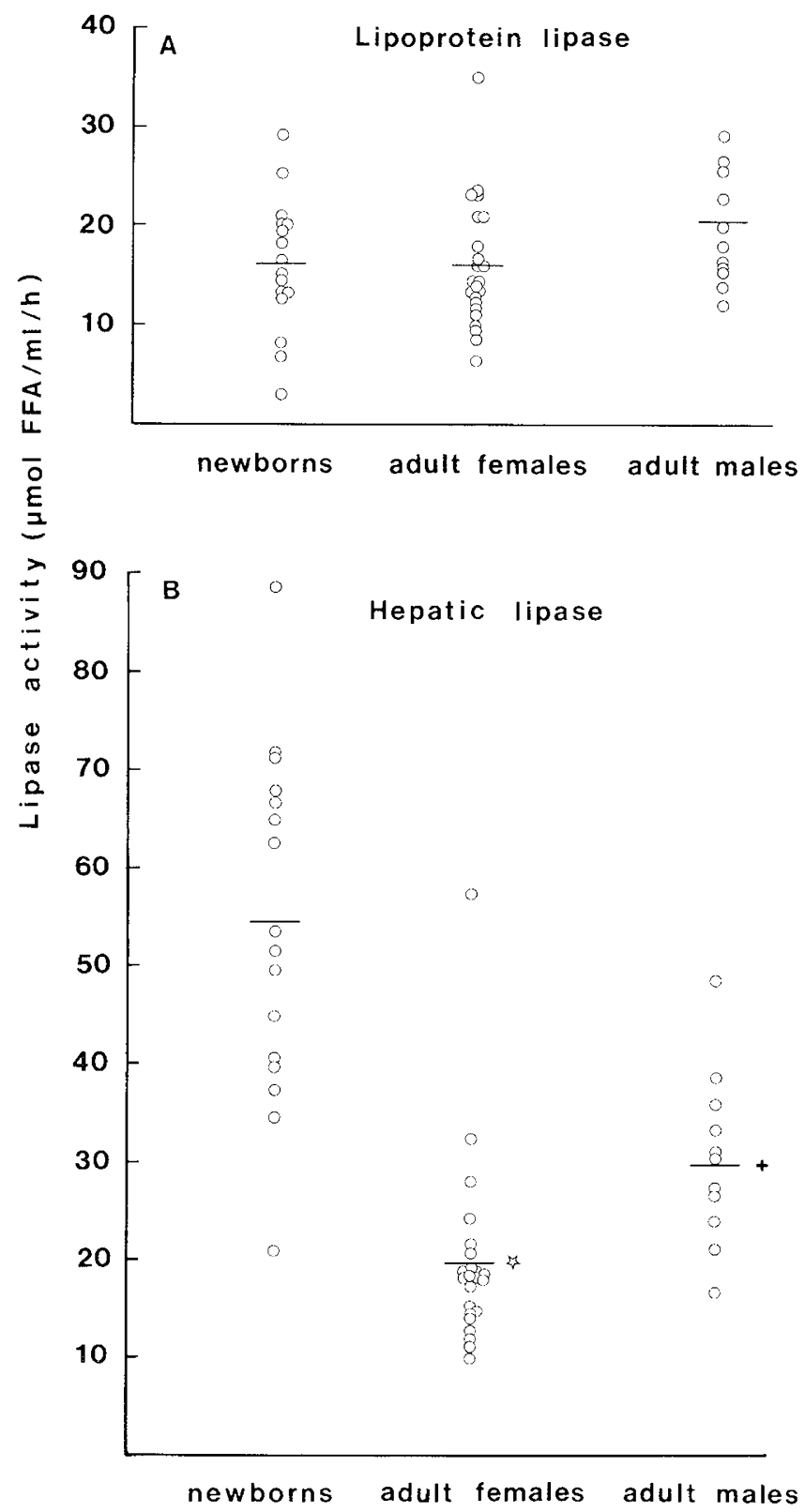

Fig. 1. Lipoprotein and hepatic lipase activities in newborns and in voluntary adult controls. Activities of lipoprotein lipase $(A)$ and hepatic lipase $(B)$ in 16 newborns and in 23 female and 11 male adults were measured $15 \mathrm{~min}$ after a heparin bolus of $100 \mathrm{IU} / \mathrm{kg}$. The mean activities are indicated by short horizontal lines. Significant differences, between infants and adults females, and between infants and adult males, are indicated as follows: ${ }^{*}$ for $P=0.00005 ;+$ for $P=0.0003$.

between 5 and $15 \mathrm{~min}$. In four infants, we measured the two lipase activities from a simultaneous 15-min sample taken from a scalp vein. Activities in peripheral and umbilical venous samples were found to be similar $(P>0.1)$.

In addition, we measured the activities of lipoprotein and hepatic lipases in four infants after $10 \mathrm{IU} / \mathrm{kg}$ of heparin and in another four infants after $50 \mathrm{IU} / \mathrm{kg}$. As Figure 2 shows, both lipase activities were higher after 100 than after $10 \mathrm{IU} / \mathrm{kg}$ of heparin $(P<0.01)$. The lipase activities after $100 \mathrm{IU} / \mathrm{kg}$ of heparin were also higher than the activities after $50 \mathrm{IU} / \mathrm{kg}$ (Fig. 2 ); the difference was, however, not statistically significant. With $10 \mathrm{IU} / \mathrm{kg}$ of heparin, lipoprotein and hepatic lipase activities were higher at 5 than at $15 \mathrm{~min}(P<0.05)$; with $100 \mathrm{IU} / \mathrm{kg}$ the relationship reversed.

Lipase activities during exchange transfusion. During exchange transfusion, we measured the lipoprotein and hepatic 


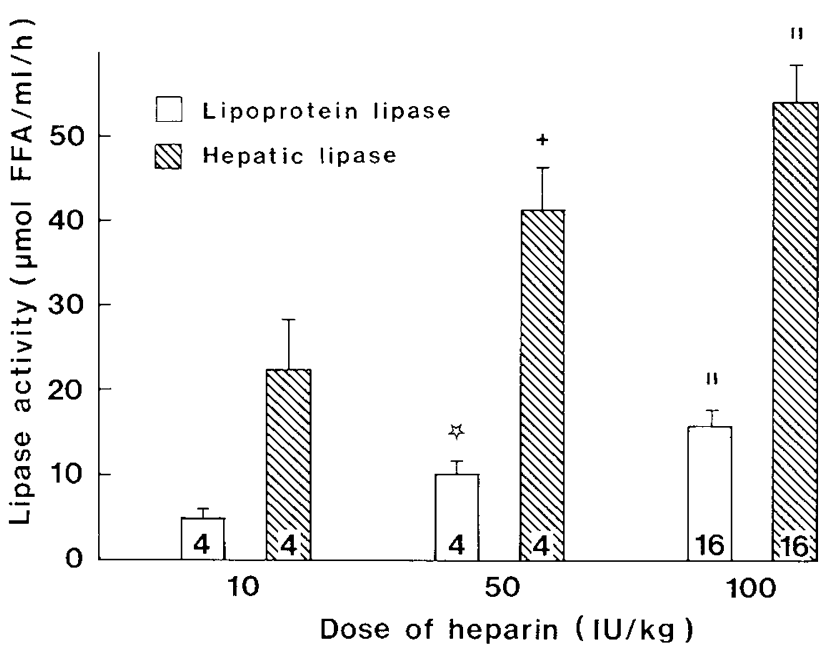

Fig. 2. Heparin dose and plasma lipase activities. Lipoprotein and hepatic lipase activities (mean \pm SEM) 5 min after a heparin bolus of $100 \mathrm{IU} / \mathrm{kg}$ and $15 \mathrm{~min}$ after a bolus of 50 and $100 \mathrm{IU} / \mathrm{kg}$. The number of infants is indicated at each column base. Significant differences, in comparison with a bolus of $10 \mathrm{IU} / \mathrm{kg}$, are indicated as follows: ${ }^{*}$ for $P=$ $0.010:+$ for $P=0.041 ; \|$ for $P=0.003$.

lipase activities of the 16 infants who had received a heparin bolus of $100 \mathrm{IU} / \mathrm{kg}$. The donor blood used contained no measurable lipase activities. The exchange started $15 \mathrm{~min}$ after the heparin bolus (Fig. 3). Blood samples were taken, on the average, at 45 and $81 \mathrm{~min}$ when 100 and $200 \mathrm{ml} / \mathrm{kg}$ of blood had been exchanged. The mean lipoprotein lipase activity remained almost unchanged during the exchange transfusion (Fig. $3 A$ ). In contrast, the mean hepatic lipase activity decreased considerably (Fig. $3 B$ ): at 45 min the activity was $47 \%$ and at $81 \mathrm{~min} 25 \%$ of the initial value measured at $15 \mathrm{~min}$.

The heparin bolus was $100 \mathrm{IU} / \mathrm{kg}$ and the transfusion was performed with fresh heparinized blood containing $4.5 \mathrm{IU} / \mathrm{ml}$. Hence, the heparin concentration $(\mathrm{IU} / \mathrm{kg}$ ) increased with the amount of blood exchanged. Figure $3 C$ shows the estimated upper and lower limits of the heparin concentration. The mean heparin concentrations estimated were 255 and $285 \mathrm{IU} / \mathrm{kg}$ when 100 and $200 \mathrm{ml} / \mathrm{kg}$ of blood had been exchanged. Approximately $92 \%$ of the infant's blood was replaced. Hence, no more than about $8 \%$ of the lipoprotein and hepatic lipase activities, released during the first $15 \mathrm{~min}$, could have been in the circulation at the end of the exchange. Therefore, it is remarkable that lipoprotein lipase activity remained constant. The increase of the heparin concentration estimated, however, provides a plausible explanation $(19,40)$.

One infant underwent three exchange transfusions within 24 $\mathrm{h}$. The interval between each transfusion was about $12 \mathrm{~h}$. The lipase activities measured during the first and the third exchange were similar, however. Thus, although considerable amounts of lipoprotein and hepatic lipase activities were removed, both lipases were evidently regenerated within $12 \mathrm{~h}$.

\section{DISCUSSION}

The infants studied underwent an exchange transfusion because of blood group incompatibility, hyperbilirubinemia, or polycythemia. The parameters of fat and carbohydrate metabolism were not affected by abnormalities in hemoglobin level, reticulocyte count, or bilirubin concentration; they were similar to those of healthy full-term newborns $(7,13,16,34,39)$. Hence, we consider the infants of the present study to have normal carbohydrate and lipid metabolism.

Lipoprotein and hepatic lipase activities have not been previously measured in infants. We found lipoprotein lipase activities to be similar in full-term newborn infants and adults. Hence, clearance of fat from the circulation should be as effective in
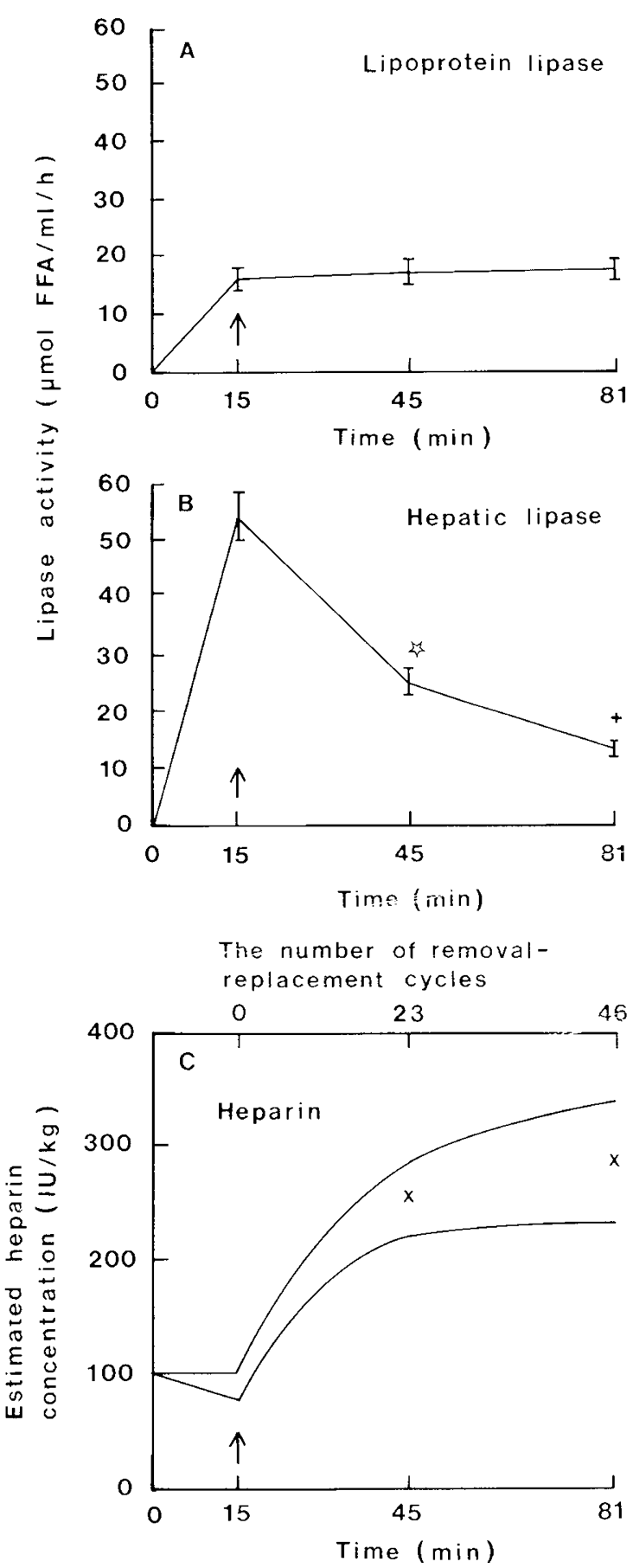

Fig. 3. Lipase activities and estimated heparin concentration during exchange transfusion (mean \pm SEM of 16 infants). As arrows indicate, exchange transfusion started $15 \mathrm{~min}$ after a heparin bolus of $100 \mathrm{IU} / \mathrm{kg}$ $A$, Lipoprotein lipase. $B$, Hepatic lipase; significant differences in cornparison with the activity at $15 \mathrm{~min}:{ }^{*}$ for $P=0.00025$; + for $P=0.00020$ C. Estimated upper and lower limits of heparin concentration during exchange transfusion. ${ }^{1}$ Crosses indicate the mean heparin concentrations at 45 and $81 \mathrm{~min}$

'Assuming that no heparin is metabolized, we estimated the upper limit of heparin concentration ( $\mathrm{IU} / \mathrm{kg}$ ) during exchange transfusion with the following equation:

$$
H(k=(1-0.0536) H(k-1)+19.29 \mathrm{IU} / \mathrm{kg}
$$

where $H(k-1)$ is the heparin concentration before the $k$ th removal and $H(k)$ is the heparin concentration after $k$ th replacement. The number of removal-replacement cycles are as indicated. The constants were calculated as follows: each $15 \mathrm{ml}$ of blood removed was $5.36 \%$ of the total blood volume, calculated as $8 \%$ of the body weight $(25,26)$; each $15 \mathrm{ml}$ of blood replaced contained $67.5 \mathrm{IU}$ of heparin and added $19.29 \mathrm{IU} / \mathrm{kg}$ to the heparin concentration. The lower limit of the heparin concentration during exchange transfusion was estimated assuming a heparin halflife of $39 \min (27)$. 
newborn infants as in adults. However, in premature infants this may not be true $(8,41)$. On the other hand, the mean activity of hepatic lipase in newborn infants was considerably higher than in adults.

In accordance with previous studies $(7,10,34,39)$, we found that triglyceride and cholesterol concentrations increased with postnatal age but the cholesterol/triglyceride ratio remained unchanged. Lipoprotein lipase activity was, however, independent of age whereas hepatic lipase activity increased with age.

In agreement with prevous studies $(7,10,19,32,34)$, we found that triglyceride and cholesterol concentration and their ratio were lower in infants than in adults. In adults, there is a positive linear correlation between lipoprotein lipase activity and HDLcholesterol $(31,38)$. In accordance with previous studies $(16,34)$, we found also that the HDL-cholesterol concentration in infants was about half of the concentration in adults. Lipoprotein lipase activities were, however, similar in infants and in adults.

Insulin is a known activator of lipoprotein lipase $(2,6,12,30$, 33). Comparing infants younger and older than $48 \mathrm{~h}$, we found that the insulin concentration decreased with age but lipoprotein lipase activity was independent of age. However, this finding may at least partially result from differences between individual fasting periods.

Hepatic lipase is released from the liver $(24,30)$, which is relatively large in infants. This might partly account for the high hepatic lipase activity in infants. On the other hand, Jansen and Birkenhager (21) have shown that heparin releases liver lipaselike activity from the human adrenal glands. The relative weight of the adrenal glands in newborn infants is 30 times the relative weight in adults (28), and at the age of 3 weeks, $50 \%$ of the fetal adrenal cortex is still left (28). Hence, lipase activity released from the fetal adrenal glands may contribute to the high hepatic lipase activity in infants.

We found that the HDL/LDL ratio is about 0.8 regardless of postnatal age; in adults, the ratio is about $0.4(19,32)$. Carr and Simpson $(3,4)$ have shown that fetal adrenal cortex actively uses LDL-cholesterol for steroidogenesis, which might explain the low concentration of LDL-cholesterol in newborn infants.

A proposed function of hepatic lipase is catabolism of HDLcholesterol $(22,23)$. If part of the hepatic lipase activity measured is, indeed, of adrenal origin, this part could promote the use of HDL-cholesterol, in addition to LDL, for steroidogenesis. This is feasible, since the HDL-cholesterol level is high compared with LDL-cholesterol level.

PHLA has been determined after a bolus of $10 \mathrm{IU} / \mathrm{kg}$ heparin $(8,20,41)$ and used as a measure of lipoprotein lipase activity $(8,20,41)$. We found, however, that $10 \mathrm{IU} / \mathrm{kg}$ released only part of the lipoprotein and hepatic lipase activity. These two lipases comprise $95 \%$ of PHLA (18) and we found that in infants the mean hepatic lipase activity was 3.4 times the mean lipoprotein lipase activity. In addition lipoprotein and hepatic lipase activities can vary independently. Hence, it seems unjustified to use PHLA as a measure of lipoprotein lipase.

\section{REFERENCES AND NOTES}

1. Apgar V 1953 A proposal for a new method of evaluation of the newborn infant. Anesth Analg 32:260

2. Brunzell JD. Schwartz RS, Eckel RH, Goldberg AP 1981 Insulin and adipose tissue lipoprotein lipase activity in humans. Obesity 5:685

3. Carr BR, Simpson ER 1981 Lipoprotein utilization and cholesterol synthesis by the human fetal adrenal gland. Endocr Rev 2:306

4. Carr BR, Simpson ER 1982 Cholesterol synthesis in human fetal tissue. J Clin Endocrinol Metab 55:477

5. Cheung MC, Albers JJ 1977 The measurement of apolipoprotein A-I and A-II levels in men and women by immunoassay. J Clin Invest 60:43

6. Cryer A 1981 Tissue lipoprotein lipase activity and its action in lipoprotein metabolism. Int J Biochem 13:525

7. Davis PA, Forte TM 1982 Neonatal umbilical cord blood lipoproteins. Arteriosclerosis $2: 37$

8. Dhanireddy R, Hamosh M, Sivesubramanian KN, Chowdhry P, Scanlon JW, Hamosh P 1981 Postheparin lipolytic activity and intralipid clearance in very low-birth-weight infants. J Pediatr 98:617
9. Dixon WJ 1981 BMDP Statistical Software. Berkeley, California University Press

10. Forte TM, Davis PA, Nordhausen RW, Glueck CJ 1982 The electron microscopic structure of human umbilical cord blood lipoproteins. Artery 10:223

11. Gamlen TR, Layward E, McTaggart F, Müller DPR 1981 Relationship between plasma high-density lipoprotein concentrations and lipoprotein lipase and hepatic lipase activities in children with hyperlipidaemia. Clin Sci 61:235

12. Garfinkel AS, Nilsson-Ehle P, Schotz MC 1976 Regulation of lipoprotein lipase induction by insulin. Biochim Biophys Acta 424:264

13. Ginsburg BE, Zetterström R 1980 Serum cholesterol concentration in early infancy. Acta Paediatr Scand 69:581

14. Goldberg IJ, Le NA, Paterniti JR, Jr, Ginsberg HN 1982 Lipoprotein metabolism during acute inhibition of hepatic triglyceride lipase in the cynomolgus monkey. J Clin Invest 70:1184

15. Hahn P 1978 Lipids. In: Stave U (ed) Perinatal Physiology, 2nd ed. New York, Medical Book Co, pp 397-423

16. Hardell LI 1981 Serum lipids and lipoproteins at birth based on a study of 2815 newborn infants. I. Concentration and distribution of triglycerides and cholesterol. Acta Paediatr Scand Suppl 285:5

17. Hovi L 1981 Hyperbilirubinemia of the newborn. Studies on pathogenetic mechanisms and treatment. Dissertation, University of Helsinki

18. Huttunen JK, Ehnholm C, Kinnunen PKJ, Nikkilä EA 1975 An immunochemical method for the selective measurement of two triglyceride lipases in human postheparin plasma. Clin Chim Acta 63:335

19. Huttunen JK, Pasternack A, Vänttinen T, Ehnholm C, Nikkilä EA 1978 Lipoprotein metabolism in patients with chronic uremia. Acta Med Scand 204:211

20. Högstedt B. Lindquist B 1963 Lipoprotein lipase in plasma of the neonatal newborn. Acta Paediatr Scand 52:61

21. Jansen H, Birkenhager JC 1981 Liver lipase-like activity in human and hamster adrenocordical tissue. Metabolism 30:428

22. Jansen H, van Tol A, Hülsmann WC 1980 On the metabolic function of heparin-releasable liver lipase. Biochem Biophys Res Commun 92:53

23. Kuusi T, Kinnunen PKJ, Nikkilä EA 1979 Hepatic endothelial lipase antiserum influences rat plasma low and high density lipoproteins in vivo. FEBS Lett 104:384

24. Kuusi T, Nikkilä EA, Virtanen I, Kinnunen PKJ 1979 Localization of the heparin-releasable lipase in situ in the rat liver. Biochem J 181:245

25. Maisels MJ 1980 Neonatal jaundice. In: Avery GB (ed) Neonatology, Physiology and Management of the Newborn, 2nd ed. Philadelphia, Lippincott Co, pp 473-544

26. McAvoy TJ 1979 Pharmacokinetic modeling of heparin and its clinical implications. J Pharmacokin Biopharm 7:331

27. McDonald MM. Jacobson LJ, Hay WW, Hathaway WE 1981 Heparin clearance in the newborn. Pediatr Res 15:1015

28. Migeon CJ 1981 Physiology and pathology of adrenocortical function in infancy and childhood. In: Collu R. Ducharme JR, Guyda H (eds) Pediatric Endocrinology. New York, Raven Press, pp 465-467

29. Murase T, Itakura H 1981 Accumulation of intermediate density lipoprotein in plasma after intravenous administration of hepatic triglyceride lipase antibody in rats. Atherosclerosis 39:293

30. Nikkilä EÁ, Kuusi T, Taskinen M 1982 Role of lipoprotein lipase and hepatic endothelial lipase in the metabolism of high density lipoproteins: a novel concept on cholesterol transport in HDL cycle. In: Carson A. Pernow B (eds) Metabolic Risk Factors in Ischemic Cardiovascular Disease. New York, Raven Press, pp 205-215

31. Nikkilä EA, Taskinen MR, Kekki M 1978 Relation of plasma high density lipoprotein cholesterol to lipoprotein lipase activity in adipose tissue and skeletal muscle of man. Atherosclerosis 29:497

32. Nikkilä EA, Taskinen MR, Rehunen S, Härkönen M 1978 Lipoprotein lipase activity in adipose tissue and skeletal muscle of runners: relation to serum lipoproteins. Metabolism 27:1661

33. Nilsson-Ehle P 1982 Regulation of lipoprotein lipase. In: Carson A, Pernow B (eds) Metabolic Risk Factors in Ischemic Cardiovascular Disease. New York, Raven Press, pp 49-57

34. Potter JM 1977 Perinatal plasma lipid concentrations. Aust N Z J Med 7:155

35. Schiff D, Aranda JV, Chan G, Stern E 1971 Metabolic effects of exchange transfusion. I. Effect of citrated and of heparinized blood on glucose, nonesterified fatty acids, 2-(4-hydroxybenzeazo)benzoic acid binding, and insulin. J Pediatr 78:603

36. Siegel S 1956 Nonparametric statistic for the behavioral science. McGraw-Hill Book Company, Inc. New York

37. Tan MH 1978 The lipoprotein lipase system: new understandings. Can Med Ass J 118:675

38. Taskinen MR, Nikkilä EA 1979 Lipoprotein lipase activity of adipose tissue and skeletal muscle in insulin-deficient and very-low-density lipoproteins and response to treatment. Diabetologia 17:35

39. van Biervliet JP, Vinaimont N, Caster H, Vercaemst R, Rosseneu M 1981 Plasma apoprotein and lipid patterns in newborns: influence of nutritional factors. Acta Paediatr Scand 70:851

40. Wilson DE, Glad BW, Working PK, Adler ME 1978 Postheparin plasma lipase activities in obesity: failure to increase adipose organ enlargement. Metabolism 27:1084

41. Zaidan H, Dhanireddy R, Hamosh M, Pramanik AK, Chowdhry P, Hamosh P 1982 Effect of continuous heparin administration on intralipid clearing in very low-birth-weight infants. J Pediatr 101:599 
42. Requests for reprints should be addressed to: Liisa Rovamo, M.D., Children's Hospital. University of Helsinki, 00290 Helsinki 29. Finland.

43. This research was supported by the Foundation for Pediatric Research, Hilma and Heikki Honkanen's Foundation, Foundation of Nutritional Research. Finnish Academy, Finnish Foundation for Culture, Huhtamäki OY, Leiras
Pharmaceuticals, Sigrid Juselius Foundation, and Nordisk Insulinfond. 44. We thank Sirkka Runeberg. Paula Teräväinen, and Hannele Hilden for their skillful technical assistance.

45. Received for publication September 27, 1983

\title{
Diamine Oxidase and Disaccharidase Activities in Small Intestinal Biopsies of Children
}

\author{
P. FORGET ${ }^{(8)}$ C. GRANDFILS, J. L. VAN CUTSEM, AND G. DANDRIFOSSE \\ Department of Pediatrics (P. F., J. L. V.C.) and Department of General and Comparative Biochemistry (C. G., \\ G. D.), Liege University, Liege, Belgium
}

\section{Summary}

A relationship between disaccharidase and diamine oxidase (DAO) activities was looked for by measuring these enzyme activities in histologically normal small intestinal biopsies of 18 children. The range for disaccharidase activities expressed in $\mathrm{U}$ $\mathrm{g}^{-1}$ wet weight was $0.1-5.7,7.1-36.7$, and $2.3-8.5$ for lactase, maltase, and sucrase, respectively. The range for DAO activities expressed in $\mathrm{nmol} \mathrm{h}{ }^{-1} \mathrm{~g}^{-1}$ wet weight was 202-974. Significant correlations were found between disaccharidase and DAO activities (lactase versus DAO: $n=17, r=0.80, P<0.001$; maltase versus DAO: $n=18, r=0.70, P<0.001$; sucrase versus DAO: $n=18, r=0.55, P<0.05$ ). Our results further support the hypothesis that DAO is a marker of small intestinal functional integrity in children.

\section{Abbreviation}

DAO, diamine oxidase

DAO is an enzyme showing a high activity in small intestinal mucosal extracts from humans and other mammalian species (4). The enzyme is localized in the cytosol fraction of mature villous enterocytes (1). The physiological function of this enzyme in the intestinal mucosa is still a matter of discussion (1). DAO activity is measurable not only in mucosal extracts but also in serum. A correlation between serum and ileal activities has been shown to exist in the rat (4).

It has been suggested that the presence of this enzyme activity in the small intestinal mucosa would reflect the presence of mature functional villous enterocytes (4). In the rat, DAO and disaccharidase activities follow a parallel increase during both intestinal maturation and recovery after intestinal injury (4). If, in children, both disaccharidase and diamine oxidase activities are characteristics of functional villous enterocytes, a correlation between these activities could exist. The present study is the first one which looks for a possible relationship between intestinal $\mathrm{DAO}$ and disaccharidase activities in children with a histologically normal mucosa.

\section{PATIENTS AND METHODS}

Eighteen children were studied. Age, sex, and clinical data are shown in Table 1.

A small intestinal biopsy of our patients was taken in order to exclude an enteropathy as a possible cause of their clinical symptoms. Informed consent was obtained for each patient. Only the results obtained in children showing no or minimal histological biopsy changes were included in this study. Biopsies were generally obtained from the distal duodenum by endoscopy (G1P, P3, Olympus). Biopsies from other intestinal parts were taken when necessary. No complications were encountered. Duodenal biopsies were wrapped in parafilm and frozen $\left(-20^{\circ} \mathrm{C}\right)$. Analysis was performed within 2 weeks.

Methods. Measurement of disaccharidase activities. The activity of lactase (EC 3.2.1.23), maltase (EC 3.2.1.20) and sucrase (EC 3.2.1.48) was measured according to the method of Dahlqvist (3). The specific activities were expressed in units $\mathrm{g}^{-1}$ wet weight of mucosa.

Measurement of DAO activities. The activity of DAO (EC 1.4.3.6) was estimated by a method close to the radiometric technique described by Okuyama and Kobayashi (6). In this method, $\left[{ }^{3} \mathrm{H}\right]$ putrescine is used as substrate. The reaction product $\left(\Delta_{1}\right.$-pyrroline) is extracted in toluene and its radioactivity is estimated by using a scintillation spectrometer (Packard, 3255).

Details were as follows. Each small intestinal biopsy was extracted in distilled water $(1 \mathrm{mg} / 200 \mu \mathrm{l})$ by using a Potter homogenizer (equipped with a glass pestle and tube). The extract was used without further treatment for the measurement of the disaccharidase activities. It was diluted 20 times in phosphate buffer $(0.1 \mathrm{M}, \mathrm{pH} 7.4)$ for the estimation of the DAO activity.

$\left[{ }^{3} \mathrm{H}\right]$ Putrescine was purchased from New England Nuclear Co. It had a specific radioactivity of $40.5 \mathrm{Ci} \mathrm{mmol}^{-1}$. Before utilization, it was mixed with unlabeled putrescine in order to reach a specific radioactivity of approximately $1 \mathrm{Ci} \mathrm{mmol}{ }^{-1}$. To determine the DAO activity, $50 \mu \mathrm{l}$ of the homogenate was mixed with $50 \mu \mathrm{l}$ of putrescine (160 pmol, yielding approximately 280,000 cpm).

The mixture was incubated at $37^{\circ} \mathrm{C}$ for variable periods $(0,10$, 20 , and $30 \mathrm{~min}$ ). The reaction was stopped by the addition of 10 